\title{
Understanding values-based food labeling as rural development strategy in Colombia. Comparative analysis: Fair trade, geographical indications and organic labels in the coffee region and the Buenaventura rural area (Phase 1)
}

\section{Entendiendo los distintivos de calidad agroalimentarios como estrategia de desarrollo rural en Colombia. Análisis comparativo: comercio justo, indicaciones geográficas y certificación ecológica en la región cafetera y la zona rural de Buenaventura (Fase 1)}

\author{
Xiomara Fernanda Quiñones Ruiz' ${ }^{1}$, Marianne PenkeR ${ }^{2}$
}

\begin{abstract}
Poverty in many rural areas of developing countries is not a new story. Rural farmers face many financial and market barriers. Furthermore, conventional farming practices are afflicted by free market pressure to produce more food for less income, resulting in destruction of the environment and neglecting human and animal welfare. Value based labeling offers alternatives to conventional food markets as they provide ethical principles to counter unsustainable trends within the capitalism system as stated by Elizabeth Barham. Hence, a planned study is aimed at evaluating selected labels such as fair trade, geographical indication/denomination of origin and organic certification in the context of the Buenaventura rural area, taking into account the lessons learned and experiences from the coffee region. Thus the labels will be explained as well as the objectives and methodology of the doctoral thesis. Finally, the findings and conclusions of the initial exploratory research draw useful insights of the current situation.
\end{abstract}

Keywords: Borojó (Borojoa patinoi Cuatr.); Chontaduro (Bactris gasipaes Kunth); Fair trade; Geographical indications; Institutions; Organic certification; Transaction costs; Property rights.

\section{RESUMEN}

La pobreza que se vive en las zonas rurales de los paises en desarrollo no es una historia nueva. Los campesinos rurales se enfrentan a barreras financieras $y$ de mercado. Además, las prácticas convencionales de agricultura se ven afectadas por las presiones del libre mercado para producir más alimentos por menos ingresos, lo que ocasiona la destrucción del medio ambiente sin tener en cuenta el bienestar de los seres humanos y animales. Como ha expuesto Elizabeth Barham, las nuevas alternativas a las prácticas agroindustriales convencionales, son los distintivos de calidad agroalimentarios y sus valores añadidos, puesto que ellos incluyen principios éticos para contrarrestar tendencias insostenibles dentro del sistema económico capitalista. Así, esta tesis doctoral se enfocará en la evaluación de los distintivos de calidad agroalimentarios tales como el comercio justo, indicaciones geográficas/ denominación de origen y la certificación orgánica en la zona rural de Buenaventura, teniendo en cuenta las lecciones aprendidas y experiencias de la región cafetera. Asimismo, se explicarán los signos distintivos al igual que
1. Doctoral student, Institute of Sustainable Economic Development, University of Natural Resources and Applied Life Sciences (Boku), Vienna, Austria.

e-mail: xiomara.quinones-ruiz@ students.boku.ac.at

2. Ao. Prof. Dr. Marianne Penker, Institute of Sustainable Economic Development University of Natural Resources and Applied Life Sciences (Boku), Vienna, Austria.

e-mail:marianne.penker@boku.ac.at

Received: September 30, 2010

Accepted: October 14, 2010 


\section{Bioetnia Volumen 7 No 2 (julio-diciembre), 2010}

los objetivos y metodología de la tesis. Los hallazgos y conclusiones de la investigación exploratoria inicial derivan claras percepciones de la situación actual.

Palabras clave: Borojó (Borojoa patinoi Cuatr.); Chontaduro (Bactris gasipaes Kunth); Comercio justo; Indicaciones geográficas; Institutiones; Certificación orgánica; Costos de transación; Derechos de propiedad..

\section{INTRODUCTION}

As native of Buenaventura* I have chosen to course my Doctoral Studies in Social and Economic Sciences with focus on Rural and Agricultural Development at the University of Natural Resources and Applied Life Sciences in Vienna (Austria), considering local rural communities and tropical fruits from the area such as peach palm, commonly known in Colombia as chontaduro (Bactris gasipaes Kunth) and borojó (Borojoa patinoi Cuatr.). These two fruits have been selected as they are the most representative crops in the zone. Table 1 briefly describes the production characteristics of the selected crops in the Buenaventura rural area. For my doctoral thesis I have decided, under the guidance and supervision of Prof. Dr. Marianne Penker, to make an empirical analysis identifying the opportunities and barriers for small holders to access and benefit from value based agro-food labels such as fair trade, organic and geographical indications (GI). The feasibility to add value to chontaduro and borojó through the implementation of value labeling in the selected localities of Buenaventura will be investigated.

The investigative study will consist of two parts:

1. Analyzing and getting in-depth knowledge about the lessons learned during the implementation of organic labels, fair trade and geographical indications for the Colombian coffee. The accumulated knowledge from long years of organic and fair trade certification as well as the geographical indication Café de Colombia, an international «success story», can be studied to identify the institutional framework and conditions for the participation of small holders in value-based agro-food labels;

2. Analyzing the opportunities and barriers for small land

* Buenaventura is located at the Colombian Pacific Coast, which is considered a region that possesses one of the major sources of biodiversity, rainforest and rainfall in the world. It belongs to the tropical Chocó Biogeográfico region. Nevertheless, this coast is one of the poorest and most vulnerable regions in the country. According to national statistics, in 2003 poverty reached $80.6 \%$ of the population in Buenaventura and extreme poverty $43.5 \%$, with an unemployment rate of $29 \%$. [Local statistics 2003 (Buenaventura) included in National Council for Economic and Social Policy (Conpes) 3410, p. 5.] holder farmers that produce, namely, chontaduro and borojó in the rural area of Buenaventura, to participate in and benefit from value-based labels in general and geographical indications in particular.

An exploratory research was carried out before starting with the planned field research in order to get local insights into the problem and context as well as to determine whether the research question and methodology should be redefined. Thus, several stakeholders such as farmers, researchers, entrepreneurs, government and university staff were interviewed.

\section{UNDERSTANDING THE VALUE LABELS: FAIR TRADE, GEOGRAPHICAL INDICATIONS (GI) AND ORGANIC CERTIFICATION}

As of Barham (2002), the values the labels promote encompass an extensive range of domains, including environmental (i.e. rain forest friendly), social (i.e. fair trade) and ethical alternatives (i.e. no animal testing). The labels send clear messages about a product's value in registers that are usually considered to be non-market by economists (Barham 2002). Thus, consumers decide to purchase value based products and pay a premium price if these extra values are being assured (Barham 2002, Penker 2006). These labels will be acknowledged as innovation systems in the agricultural production area and serve as important institutional arrangements (Sanchez 2010).

Accordingly, the planned doctoral thesis will focus on three specific value based labels, namely, fair trade, geographical indication/denomination of origin and organic certification.

The fair trade market has been established with the goal to make trade equitable for producers. Fair trade is said to give greater control to local producer, fair trade organizes local producers into democratic co-operatives and encourages integration with other actors in the supply chain for example through long term contracts (Van der Hoff Boersma 2009; Steinrücken et al. 2007). One of the main restrictions of access to the fair trade market is that the total number of growers (and the total volume of coffee) is limited due to market share and/ or the number of producers the fair trade system can reach (Muradian et al. 2005). The fair trade system for coffee features a demand/supply mismatch, giving power to the traders/roasters as to which farmers may participate or are excluded from the system (Muradian et al. 2005).

Geographical Indications are a label of origin used to protect consumers from misleading geographically labeled products. The World Trade Organization's 1994 Agreement on Trade-Related Aspects of Intellectual Property Rights defines geographical indications as «indications which identify a good as originating in the territory of a Member, 
or a region or locality in that territory, where a given quality, reputation or other characteristic of the good is essentially attributable to its geographic origin» (1994 Agreement on Trade-Related Aspects of Intellectual Property Rights, Article 22.1). Geographical Indications are a collective intellectual property right owned solely by the actors coming from a stipulated region, who also meet set certification standards. In the case of Colombia, GIs are protected by supra national regulation (decision 486 of the Comunidad Andina de Naciones).

Organic agriculture primarily applies ecological good practices in farming production, characterized by the absence of pesticides; nevertheless organic farming is also aimed at repairing the nature. The term organic refers to the way agricultural products are grown and processed (Freyer 2010). Specific requirements must be met and maintained in order for products to be labeled as organic. In Colombia some small growers are applying principles of organic farming (guided by experts) without organic certification. As of regional newspaper in Colombia (El País 2010), 10 years ago a group of farmers from San Rafael (Valle del Cauca) decided to get together and established 30 escuelas agroecológicas (noncertified organics) with the goal of protecting nature; their motto is not to use agrochemicals in their production process. These groups have the support of the CVC (Corporación Autónoma Regional del Valle del Cauca) and Mayor's Office. The communities have learned to produce their own shampoos, body creams, expectorants, soaps, toothpaste as well as composts.

\section{STRUCTURE OF THE RESEARCH: HYPOTHESES, RESEARCHQUESTION, OBJECTIVES, THEORETICAL FRAMEWORK ANDMETHODOLOGY}

Accordingly, the hypotheses of the research, research questions, objectives and foreseen methodology of investigation are presented as follow:

Hypotheses of the research

1. A suitable institutional framework can provide equitable conditions for small holder farmers of rural areas to benefit from value-based agro-food labels.

2. Lessons learned fromorganic labels and fair trade regarding a supportive institutional framework for small holder participation can be transferred and adapted to geographical indications.

3. Value based labels can be powerful development tools for rural areas, in terms of livelihood, well being, social cohesion as well as the protection of the local environment, local knowledge and cultural practices of production.

Research question. What are equitable conditions to encourage small holder access to and benefit from value- based agro-food labels (GI, Organic, Fair Trade), with specific relevance to the selected crops in the rural area Buenaventura and deprived rural areas in general?

\section{Research objectives}

1. To expose conditions that (dis-)favor small holder access to and benefit from fair trade and organic markets (by taking into account the growing body of literature on these two comparatively established labels and amplifying it with empirical evidence from the leading Colombian coffee region).

2. To identify the current climate for small holder participation in the market of geographical indication in the coffee region, taking into account the experience of Café de Colombia.

3. To analyze potentials of and barriers for the implementation of GI for tropical fruits produced in the selected areas of Buenaventura. The areas will be jointly selected with stakeholders in the region.

4. To suggest favorable conditions for small holder access to and benefit from value-based agro-food label in general and geographical indication in particular.

Theoretical framework. The theoretical framework that will be applied to the proposed research is institutional analysis with a particular focus on property rights and transaction costs analysis. As of Ostrom (2005, Nobel Prize in Economic Sciences 2009), contextual variables are essential for understanding the initial growth and sustainability of collective actions as well as the challenges that self-organized systems (i.e. institutions) should try to overcome. North (1990) defines institutions as the «rules of the game» which in this case consist of formal and informal rules governing the supply chain actors. The players of the game are the actors along the supply chain and involved governmental, production, industrial, research or educational organizations which are comprised of individuals who share common objectives.

The transaction costs analysis will focus on the main actors of the food chain from production to retailing; taking into account the allocation of transaction costs of value based labels but also the associated benefits and risks. Transaction costs account for additional expenditure such as the energy and effort required to obtain required information, direct monetary expenditure and work time lost to meetings, communication, negotiations and conflict settlement occurring in the co-operation along value-based food supply chains.

Property rights are a useful analytical concept to scrutinize and understand current rural dynamics and conflicts (Laschewski and Penker 2009). Property rights and governance of quality constructions are fundamental to establish who benefits from value differentiation (González et al. 2005; Muradian et al. 2005). The proposed property rights analysis will look into the formal (intellectual) property rights associated 


\section{Bioetnia Volumen 7 No 2 (julio-diciembre), 2010}

with value-based labels, as well as individual entitlements to make use of the certification process.

\section{METHODOLOGY}

Based on the state of art in empirical institutional analysis, this study will refine the concepts of common (intellectual) property and private transaction costs. Yin's (2003) case study approach will be employed to allow the gathering of detailed and context specific knowledge on the three valuebased food labels in the coffee region as well as on the institutional framework shaping the production, processing and retailing of selected tropical fruits in the Buenaventura region. Apart from semi-structured interviews with representatives of involved organizations (e.g. local farmer associations) and individual supply chain actors, the analysis of relevant documents (product specifications, contracts, legal regulations, etc.) and secondary market and regional economic data will provide help in understanding how institutions build, shape and reproduce the supply chains over time and space (Marsden et al. 2000). The transdisciplinary framework will take into account the knowledge, skills of and collaboration among local stakeholders in order to support mutual learning between Austrian and local scientists and stakeholders involved in the international supply chains.

\section{FINDINGS OF THE INFORMAL EXPLORATORY RESEARCH}

Interviews were scheduled with diverse actors as listed in Table 2. The visits were carried in a two week period from 3 to 16 September 2010.

The specific objectives of the exploratory research were:

1. To identify the relevant actors in the fruit and coffee production. Who are the most relevant actors?

2. To get better insights into the problems related to the value chain of fruits and processed products. What are the main problems surrounding the production and commercialization of chontaduro and borojó?

3. To find out new inputs/information. What is the novel information found?

4. To determine if a refinement or adjustment of the research focus (i.e. research questions, aims) is necessary. Is there any necessary adjustment to be done in the already defined investigative project?

1. Who are the most relevant actors? Table 2 already summarizes the main actors. Besides farmers, farmer associations and the consejos comunitarios, the research institutions such as Centro Internacional de Agricultura Tropical (CIAT) and local universities play an important role for the investigative study. In addition, companies as well as platoneras (women that sell cooked chontaduro in the cities, namely in Cali) are crucial in the processing and commercialization process. Local government institutions such as CVC and Instituto de Investigaciones Ambientales del Pacífico (IIAP) are also crucial entities as they promote rural and agricultural development in the zone.

2. What are the main problems surrounding the production and commercialization of chontaduro and borojó?

Production situation. Three farms in Triana, Bajo Calima and Sabaletas were visited respectively. The farms were selected, under the guidance of CVC Buenaventura, due to the proximity to the area and development level of farms. It was found that some farms have been abandoned by cultivators or destroyed due to the illegal extraction of gold alongside the Dagua river banks; moreover, this situation has increased the already present insecurity and armed conflict in the area. A considerable erosion of the terrain was observed in this zone. No monocultures were found. Livestock husbandry was found in one farm only. No values added labeling was found in the fruit region.

The main technical problems for the chontaduro are the treatment of plagues, the crop varieties that hinder the control of diseases and the insecure harvesting methods, as there is always a danger in harvesting the chontaduro, farmers may fall due to the considerable height of palms (up to 20 meters). These issues are being investigated by CIAT, experts, professors and local universities. For instance, CIAT staff and farmers have identified a new plague (insect) that affects the chontaduro. According to the information collected, CIAT will be a good source for technical information related to the farming of chontaduro. As they are still carrying out studies, their findings cannot be published. In the case of borojó, no sufficient technical information was provided, the visited borojó trees were not affected by plagues.

Farm 1. This farm has a large number of fruit trees, namely, peach palm, borojó, bread trees, bamboos, custard apple, apple bananas, bananas, plantains, lemons, avocados, cacao, among other fruits and trees for agro-forestry. A member of the consejo comunitario served as guide during the visit to the farm, as the owner of the farm was not present at the time of visit. The guide tried to show other farms but they were covered by weeds what made it difficult in that particular moment. Peach palms have been affected by insects in the Triana region. No scientific names of plagues were identified at this time; however, CIAT and local experts have categorized the plagues that affect chontaduro.

Farm 2. Members of the consejo comunitario of Bajo Calima and of the IIAP in the area guided the visit to the farm. The farmer said to own 10 hectares, in which chontaduro, cacao and some plantains are cultivated. The farm is surrounded by streams. Two trout farms were found with five hundred fishes each. In addition, there is poultry for egg and 


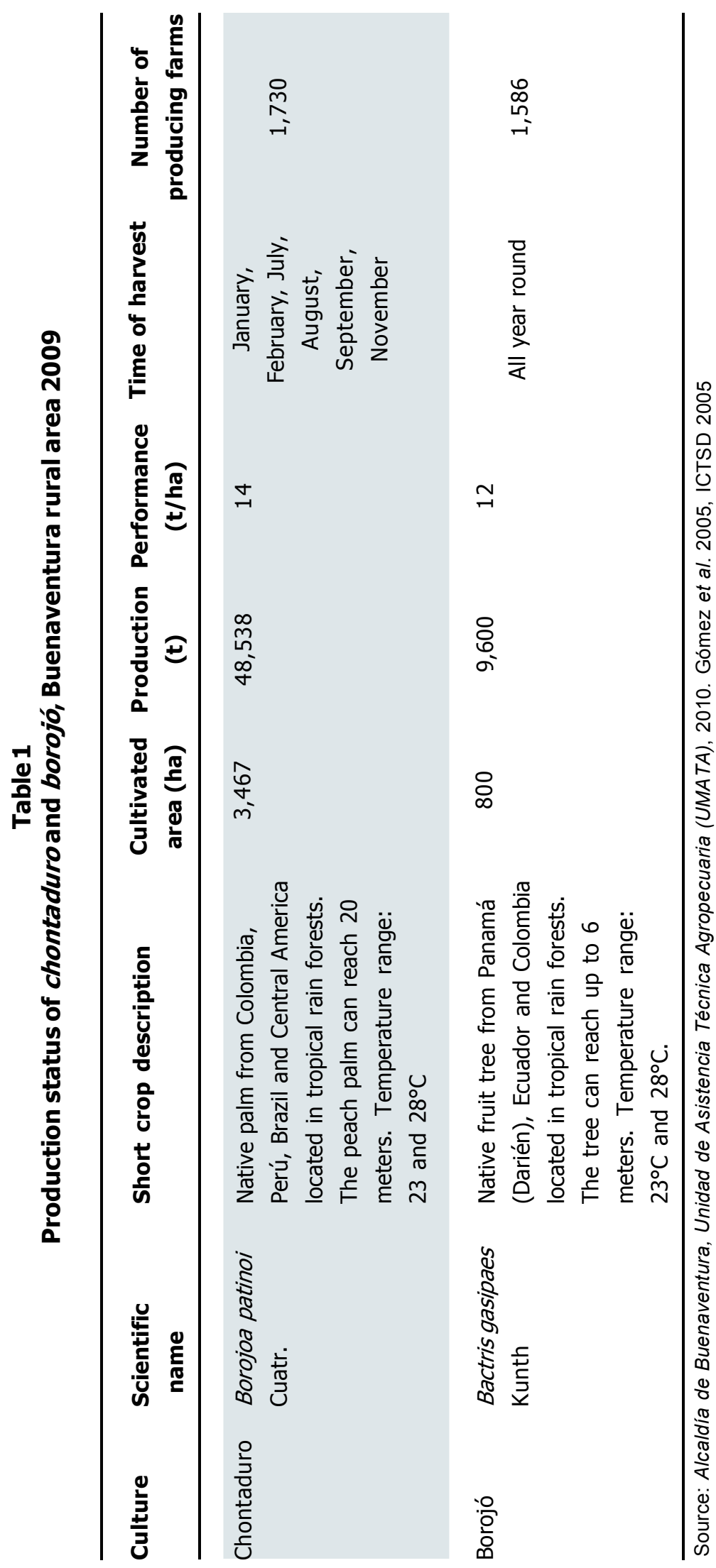

meat production. The farmer stated that organic fertilizers are used for the peach palm. Plague infestation was not perceived; however, no samples were taken for in depth observation.

Farm 3. The farmer visited cultivates fruit trees such as chontaduro, borojó, guava, plantains and acai palm in its 4 hectares. One of the sons served as guide and explained the situation in the farm. The son stated that they only use pesticides for the peach palm; however, he said that the residues of pesticides may be found in other crops. The chontaduro is a native fruit of the Amazonas; this motive and the extended cultivation of the crop (the boom of chontaduro) have caused the propagation of plagues. He also stated that although chontaduro and borojó compete for soil nutrients, the last needs the shadow of the palm; consequently, a distance of at least 10 to 15 meters is needed for their respective farming. Currently, they are producing yogurts, marmalade, arequipe de borojó, chontaduro in syrup and cakes. A group of farmers of Sabaletas is promoting its own mark called Arakatanga, but it was also perceived that only few farmers are involved in the creation and application of the mark. The yogurts still need the certification of the Instituto Nacional de Vigilancia de Medicamentos y Alimentos (Invima). It is worth mentioning that along the rural area of Buenaventura there are approximately 41 consejos comunitarios and the mark is only being implemented by one.

Processing and commercialization situation. In both cases (chontaduro and borojó), it was observed that there are various intermediaries along the value chain, namely in the commercialization stage. This means that there is an increase in price but there is no value added to the product. The case is more dramatic with chontaduro, in which intermediaries can be up to three along the value chain.

One company was visited, namely, a family business set up in 2005; run by the son and founded by the father who is very knowledgeable of borojó and has been in contact and experiencing with this crop for more than 23 years. It was stated that borojó and coffee belong to the rubiaceae family. The main crops the company uses for producing pulps, beverages, marmalades, yogurt, cakes and pills are chontaduro, borojó, noni and tamarind. The company buys the raw material directly from intermediaries. There is no 
Bioetnia Volumen 7 No 2 (julio-diciembre), 2010

Table 2

List of main actors found during exploratory research

\begin{tabular}{|c|c|c|c|}
\hline Sector & Actor & Place & $\begin{array}{c}\text { Date of visit } \\
\text { Sep., } 2010\end{array}$ \\
\hline \multirow[t]{3}{*}{ Farming } & Farmer $1 /$ Member of consejo comunitario & Triana, Buenaventura & 9 \\
\hline & Farmer $2 /$ Member of consejo comunitario & Bajo Calima, Buenaventura & 9 \\
\hline & Farmer 3/Member of consejo comunitario & Sabaletas, Buenaventura & 9 \\
\hline \multirow[t]{4}{*}{ Industry } & C.I. Borojó de Colombia SA & Cali & 3 \\
\hline & Federación Nacional de Cafeteros (FNC) & Buenaventura & 7 \\
\hline & Federación Nacional de Cafeteros (FNC) & Bogotá & 14 \\
\hline & Federación Nacional de Cafeteros (FNC) & Bogotá & 15 \\
\hline \multirow[t]{6}{*}{ Government } & Corporación Autónoma Regional del Valle del & & \\
\hline & Cauca (CVC) & Buenaventura & 7 \\
\hline & Alcaldía de Buenaventura, Unidad de Asistencia & & \\
\hline & Técnica Agropecuaria (UMATA) & Buenaventura & 8 \\
\hline & Instituto de Investigaciones Ambientales del & & \\
\hline & Pacífico (IIAP) & Buenaventura & 8 \\
\hline Education & Universidad del Pacífico & Buenaventura & 8 \\
\hline Cooperation & Corladesa Non Government Organization (NGO) & Cali & 10 \\
\hline \multirow[t]{4}{*}{ Research } & Bioversity International & Cali & 6 \\
\hline & Centro Internacional de Agricultura Tropical (CIAT) & Cali & 6 \\
\hline & Corporación Biotec & Cali & 6 \\
\hline & Centro Internacional de Agricultura Tropical (CIAT) & Cali & 16 \\
\hline
\end{tabular}

direct contact with farmers. It was said that in some cases, farmers exchange their raw material for other types of products. The finished goods are found in one large super/hyper market in Cali called La 14. At present the enterprise is planning the distribution of some products to other Colombian cities through different supermarkets such as Carrefour, Olímpica, Comfandi, Superinter, Mercamío and Almacenes Éxito. The target export market to date is located in Spain, Romania, France, United States, United Arab Emirates and Lebanon; in addition, there are some attempts to penetrate the Japanese market. Nevertheless, the export market share is still small and irregular. The pills are not yet exported to the Middle East as they are still in the process of certification to be granted by Invima and it was also stated that large pharmaceutical companies may be interested in acquiring the company recipe. In addition, this enterprise is facing problems due to the revaluation of the Colombian peso and the weak marketing strategies. The company obtained the ISO 9001:2008 certification in July 2010 valid until July 2013.

The platoneras are women displaced from their zones of origin (i.e. due to the presence of paramilitary groups or guerrillas) or that have the tradition of selling this crop. It was also stated that common characteristics of these women are their origin and race (Colombian Pacific Coast), place of living (marginal areas of Cali) and the considerable number of children that may not be able to attend schools.

Currently, Acción Social (Colombian National Agency for Cooperation) in agreement with Corladesa (NGO dealing with the promotion of productive programs, mainly in recycling, youth and women entrepreneurial development) are implementing two programmes that promote the saving culture of the platoneras and the creation of bank accounts, as they pay considerable interest rates to private lenders. However, until now, these women are still skeptic of banks and prefer to pay high interest rates. The government has even created insurances in case they do not pay back their credits, but this seems not to work until now. There is another initiative which is the creation of chontomóviles. These are small stands in which the chontaduro will be sold. The chontomóvil was designed by a student of Universidad Nacional de Palmira. As of the director of Corladesa, the chontomóvil will enable the sales of chontaduro in a more presentable and innovative way. The goal is to have 100 chontomóviles in strategic zones in Cali. An important input provided by the Director of 
Corladesa is that through the installation of the chontomóviles in exclusive hotels or at the airport of Palmira, the consumption of chontaduro may be regarded as a more sophisticated and innovative product to be consumed by nationals and foreigners. A recent big achievement stated by Corladesa is that there are already 3 chontomóviles at Hotel Radisson, Comfandi and Universidad Santiago de Cali. Likewise, it was stated that there are current experiments by students in making snacks such cheetos out of chontaduro.

Intermediaries and oligopoly surrounding the commercialization of chontaduro as well as the armed conflict and the cultivation of illicit crops in the region are significant adverse factors that also affect the production and commercialization of chontaduro and borojó.

3. What is the novel information found? An important outcome of the exploratory research was the access to statistics concerning cultivated area, crops, output and performance in the Municipality of Buenaventura, which is mainly located in the rural area.

A useful project methodology was presented by Bioversity International that addresses the value chain of chili in a regional project implemented in Bolivia and Peru. Thus, the lessons learned during the implementation of this project will provide inputs for the foreseen investigative project to be carried out in the Buenaventura rural area.

It was also perceived that there are outstanding educational institutions such as the Universidad del Pacífico located close to the target area with extensive technical knowledge of local varieties (biodiversity) in the Pacific region. However, it was also observed that the local university visited is lacking infrastructure(i.e. laboratories) for developing experiments and specific research.

The Director of Corporación Biotec is very keen to collaborate with the proposed investigative project. In addition, another type of label/certification called Agricultura Saludable was presented; this label is being implemented by Corporación Biotec in partnership with a group of institutions, companies and farmer associations. The concept of Agricultura Saludable supports three pillars: 1) agricultural production contributing to food security 2) high value added generation, through specialized production chains (i.e. gastronomy, industry, nutraceuticals and cosmeceuticals) and 3) environmental friendly production (Sánchez, 2010). Some of the main results to date are i) the associability and design of the brand logo, management and implementation scheme and ii) the application of a pilot project in Padilla, located in the Northern part of the Cauca State in Colombia, in association with the NGO Corporación Vallenpaz and Agrocauca, which is the farmer association specialized in the production of plantain (Musa paradisiaca L). The concept and mechanism of Agricultura Saludable will also be studied during the planned field research, since its principles and area of application will provide valuable inputs for the production, institutional and organizational analysis. Furthermore, the target population and products are comparable to the socioeconomic conditions and production process in the rural area of Buenaventura. The Director of Corporación Biotec highlighted the importance of the studies made by Elinor Ostrom related to the institutional sustainability for collective actions.

Regarding the coffee production and experience, Federación Nacional de Cafeteros (FNC) stated that the port of Buenaventura is responsible for most of the coffee exports in Colombia, mainly to Asian markets. A staff of the commercialization unit made a complete presentation of the Colombian specialty coffee program and sustainable certifications. Thus, valuable information about the different types of coffee (i.e. fair trade, organic, rain forest) and their location within the country was shown.

As of the Colombian context, geographical indication has only been applicable in the European Union. Nevertheless, the FNC is trying to introduce geographical indications in Colombia. Approximately, in mid 2010, the FNC obtained the authorization that recognizes Café de Colombia geographical indication in the country.

Furthermore, the FNC is developing the denomination of origin for two states, namely, Cauca and Nariño that have similar coffee characteristics. It was said that this is a very high quality coffee. Diverse technical studies have been carried out, supported by specific and advanced technology that among other things identifies and protects the specific characteristics of the coffee.

It was explained that implementing denomination of origin is a non ending process, as the development of marks or denomination of origin is a constant development process. It was also explained that denomination of origin in the American continent has to be understood with another focus that differs from the European vision. While the denomination of origin in Europe started many centuries ago as a result of the rules made by kings or dukes who defined the type of product and regions under their legislation; in the American continent, the denomination of origin has started as a correlation of cultural, climatic and production conditions of a product and region/zone.

4. Is there any adjustment to be done in the already defined investigative project? The information and data collected during the short visit provided already crucial insights for the developing of the doctoral thesis and the planned field research. The results in the field validate the key concepts (transaction costs, property rights, institutions) stated in the research proposal. The current findings already provide insights and hints on how to address the research question and sampling definition. The mark created in the target region is already a big success and it could be perceived as a first step 


\section{Bioetnia Volumen 7 No 2 (julio-diciembre), 2010}

to create value added labels. Important issues to study are the alternatives to pesticides in the case of chontaduro and the absence of livestock husbandry. It will be quite useful to analyze the relationship between the consejos comunitarios and their institutionalism (cooperation, competition, is there a way to foster coopetion among farmers?) in order to study associability issues; at first glance this seems to be a challenging matter. The Agricultura Saludable and Arakatanga labels will provide useful insights about the associative process experienced by farmers.

It is worth mentioning that the conditions of Buenaventura are very specific, for instance the situation with the armed conflict, illicit drugs and the fact that it is also a seaport. The research question will mainly be answered taking into account the Buenaventura context and characteristics. In addition, the exploratory research suggests the necessary material and tools, possible hurdles and precautions to be taken into account when carrying out the field research.

\section{CONCLUSIONS}

The initial impressions after this first visit were positive as there are many institutions surrounding the production of tropical fruits in the area. Furthermore, valuable information (i.e. Arakatanga, Agricultura Saludable labels) and contact details for the preparation of the field research were obtained. Likewise, it is likely to involve individuals with diverse backgrounds to promote the creation of joint base knowledge (transdisciplinary research).

It was realized that the market of chontaduro and borojó, although occupies a small market share in comparison to Colombian traditional fruits (i.e. banana, pine apple), has a growing trend and manages a considerable turnover. In addition, there is a pool of research, private and government institutions that are supporting the development of these crops. The role and participation of these institutions will be crucial in the development of the next field research.

The chontaduro has been investigated by international research centers such as CIAT and local universities. In addition, studies of how to organically handle the peach palm have been started. Furthermore, the fact that the Universidad del Pacífico is situated close to the rural producers may offer incentives for local people, professors and experts to further analyze these crops.

The Agricultura Saludable label being currently implemented by Corporación Biotec and partners shows the current experience made by farmers that have organized themselves and created a label with support of experts and NGOs. Hence, additionally to the coffee experience with fair trade, organic coffee and geographical indication, the Agricultura Saludable label will also be included in the analysis and future field research, since the experience and organizational characteristics of the target community and crops are similar to the target conditions and population in Buenaventura. It is well-known that behind the coffee industry there are supportive institutions and prominent personalities promoting the sector.

The communities have long tradition in cultivating these crops and some of them are already providing value added to their produce. For instance, yogurt, cakes or marmalade made by farmers can be found in the rural area of Buenaventura. This implies that certain ownership/property right has been achieved though the participants are still few. In addition, tourists have the opportunity to taste these products as the goods from the zone are not yet found in supermarkets. The current market shows that there is potential for these crops; however, the investigative study will be mainly focused on the local and national consumption with some market exploration in Europe (i.e. Spain). Nevertheless, it is worth mentioning that the promotion of regional and national consumption is crucial for the take-off of these products that are historically known as consumption goods of low social classes in Colombia.

Likewise, the most critical aspect surrounding the chontaduro and to a lesser extend the borojó is the security issue. It was mentioned that there are a small number of sellers (oligopoly) surrounding the commercialization of chontaduro. Regarding the borojó no information related to monopolies and commercialization was given. Moreover, it has been said that in the rural and urban zone of Buenaventura, there is presence of paramilitary groups that have the control of lucrative activities (businesses). In addition, in remote rural areas there is existence of illicit crops (coca plantations). The situation is very critical in the region, although there are international projects that have been implemented or are being implemented at present.

Please kindly contact the author in case there is additional information to share or to point out.

\section{REFERENCES}

Barham, E. 2002. Towards a theory of values-based labeling. Agriculture and Human Values. 19: 349-60.

El País. 2010. Pequeños agricultores siembran su saber en San Rafael. En línea. [fecha de acceso: 30 de septiembre de 2010]. URL disponible en: http:// www.elpais.com.co/elpai s/valle/noticias/pequenos-agricultoressiembransu-saber-en-san-rafael

Freyer, B. 2010. Script: Organic Farming in Tropical and Subtropical Regions. Vienna: Institute for Organic Farming, University of Applied and Life Sciences.

Gómez, C., Godoy, S., Díaz, D., Luna, G., Motta, E. 2005. Conserves of chontaduro standardization as alternative for the strengthening of the «minicadenas» of Bactris gasipaes in the department of Cauca, p. 81. En línea. [fecha de acceso: 10 de octubre de 2010]. URL disponible en: http:/ /www.unicauca.edu.co/biotecnologia/ediciones/vol3/Art311.pdf

González, A., Nigh, R. 2005. Smallholder participation and certification of organic farm products in Mexico. J Rural Stud. 21: 449-60.

ICTSD (International Centre for Trade and Sustainable Development) 2005. 


\section{Values-based labels as rural development strategy in Colombia. XF Quiñones, M Penker}

Taller técnico: El uso de indicaciones geográficas, denominaciones de origen o marcas colectivas para promover el desarrollo sostenible y el biocomercio. UNCTAD BIOTRADE, ICTSD, SPDA, CAN. 20-2 November 2005, Lima, Perú. En línea. [fecha de acceso: 10 de octubre de 2010]. URL disponible en: http://ictsd.org/i/events/dialogues/35829/ ?view $=$ documentation

Laschewski, L., Penker, M. 2009. Rural change and the revalorisation of rural property objects. Editorial of the Special Issue on Rural Change: Revalorization of property objects and the institutionalization of (new) property rights. IJARGE. 81: 1-13.

Marsden, T., Banks, J., Bristow, G. 2000. Food supply chain approaches: exploring their role in rural development. Sociologiy Ruralis. 40: 424-38.

Muradian, R., Pelupessy, W. 2005. Governing the coffee chain: The role of voluntary regulatory systems. World Development 33: 2029-44.

National Council for Economic and Social Policy (Conpes) 3410, p. 5. En línea. [fecha de acceso: 11 de octubre de 2010]. URL disponible en: http:// www.acnur.org/biblioteca/pdf/5488.pdf

North, D. C. 1990. Institutions, institutional change and economic performance. Cambridge: Cambridge University Press; p. 3.

Ostrom, E. 2005. Understanding institutional diversity. Princeton: University Press; p. 254-88.
Penker, M. 2006. Mapping and measuring the ecological embeddedness of food supply chains. Geoforum. 37: 368-79.

Sánchez, M. 2010. Paper: Healthy agriculture, agricultural conversion to alleviate hunger and poverty. Corporación Biotec. En línea. [fecha de acceso: 30 de septiembre de 2010]. URL disponible en: http:// www.isda2010.net/var/isda2010/storage/original/application/1bb5aafc66d 56e40bc34ed2c8ddaf060.pdf

Steinrücken, T., Jaenichen, S. 2007. The Fair trade idea: towards an economics of social labels. Journal of Consumption Policy. 30: 201-17.

van der Hoff Boersma, F. 2009. The urgency and necessity of a different type of market: the perspective of producers organized within the fair trade market. Journal of Business Ethics. 86: 51-61.

Vogl, C. 2010. Power point presentation: Food safety and quality in organic farming, Summer School Organic Food Production Chain. Vienna: Institute for Organic Farming, University of Applied and Life Sciences (Boku).

World Trade Organization. 1994. Agreement on trade-related aspects of intellectual property rights, article 22.1. En línea. [fecha de acceso: 30 de septiembre de 2010]. URL disponible en: http://www.wto.org/english/ tratop e/ trips e/intel 2 e.htm

Yin, R. 2003. Case study research: design and methods. 2 nd ed. Thousand Oaks: Sage Publications. 